\title{
Hubungan Pengetahuan Dan Sikap Keluarga Dengan Pelaksanaan PHBS Rumah Tangga Di Pekon Tanjung Rejo Kecamatan Bangkunat Kabupaten Pesisir Barat
}

\author{
Umi Romayati Keswara ${ }^{1}$, Wahid Tri Wahyudi ${ }^{2}$, Andriyanto ${ }^{3}$
}

${ }^{1,2}$ Dosen Keperawatan Universitas Malahayati Lampung

${ }^{3}$ Perawat Puskesmas Bengkunat Kabupaten Lampung Barat

Email: andriyanto14@gmail.com

\section{ABSTRACT: RELATIONSHIP OF FAMILY KNOWLEDGE AND ATTITUDE WITH IMPLEMENTATION OF HOUSEHOLD PHBS IN PEKON TANJUNG REJO KECAMATAN BANGKUNAT KABUPATEN WEST COUNTRY}

Background : PHBS is still needed and practiced in daily life, because the impact of behavior on health status is quite large, so various efforts are needed to change unhealthy behavior to be healthy. Pekon Tanjung Rejo is located in Bangukunat Subdistrict, the achievement of PHBS from 2013-2016 has fluctuated, where in 2013 with the achievement of PHBS of 66.9\%, in 2014 the achievement of PHBS was 73.8\%, in 2015 of $38.07 \%$ and in 2016 it decreased again to $32.19 \%$.

Purpose : it is known the relationship between knowledge and attitudes of families with the implementation of PHBS in Pekon Tanjung Rejo Sub-District Bangkunat District West Coast District in 2019.

Methods : Quantitative research type, cross sectional design. The study population was all household heads in the puskesmas area. Sampling was purposive sampling based on the criteria desired by the researcher. The variables studied were family knowledge, family attitudes, and PHBS household arrangements. data collection using questionnaires distributed to respondents. The study was conducted in March - April 2019. Data analysis was univariate and bivariate (Chi Square).

Result : based on the results of the study most of the behavior is not household PHBS as many as 113 (64.9\%) respondents. Most knowledgeable about household PHBS is not as good as 95 (54.6\%) respondents. Most of them have negative PHBS Household attitudes as many as 93 (53.4\%) respondents. There is a relationship between knowledge with household PHBS behavior ( $p$ value 0,000; OR: 4,046). There is a relationship between attitude and PHBS behavior in the household ( $p$-value 0,000; OR: 5,316). Suggestions Pekon Tanjung Rejo Bangkunat Subdistrict in collaboration with cross-sectors to do re-triggering per $R W / R T$ in the community environment that still does not behave PHBS and provide practical stimulants related to PHBS. Conclusions : There is a relationship between knowledge and attitudes with PHBS behavior of households in Pekon Tanjung Rejo Bangkunat Subdistrict, West Coast Regency in 2019. Suggestions are expected to be more intensive and actively involved in collaboration to hold regular counseling on the importance and benefits of PHBS.

Keywords: knowledge, attitude, PHBS

\footnotetext{
Umi Romayati Keswara ${ }^{1}$, Wahid Tri Wahyudi ${ }^{2}$, Andriyanto ${ }^{3}$

${ }^{1,2}$ Dosen Keperawatan Universitas Malahayati Lampung

${ }^{3}$ Perawat Puskesmas Bengkunat Kabupaten Lampung Barat . Email: andriyanto14@gmail.com
} 


\section{INTISARI: HUBUNGAN PENGETAHUAN DAN SIKAP KELUARGA DENGAN PELAKSANAAN PHBS RUMAH TANGGA DI PEKON TANJUNG REJO KECAMATAN BANGKUNAT KABUPATEN PESISIR BARAT}

Latar Belakang: PHBS masih diperlukan dan dipraktekkan dalam kehidupan sehari-hari, karena dampak dari perilaku terhadap derajat kesehatan cukup besar, maka diperlukan berbagai upaya untuk mengubah perilaku yang tidak sehat menjadi sehat. Pekon Tanjung Rejo terletak di Kecamatan Bangukunat, pencapaian PHBS dari tahun 2013-2016 mengalami fluktuatif, dimana tahun 2013 dengan pencapaian PHBS sebesar 66,9\%, di tahun 2014 dengan pencapaian PHBS sebesar 73,8\%, ditahun 2015 sebesar 38,07\% dan ditahun 2016 mengalami penurunan kembali menjadi sebesar $32,19 \%$.

Tujuan penelitian: diketahui hubungan pengetahuan dan sikap keluarga dengan pelaksanaan PHBS Rumah Tangga di Pekon Tanjung Rejo Kecamatan Bangkunat Kabupaten Pesisir Barat tahun 2019.

Metode Penelitian : Jenis penelitian kuantitatif, rancangan cross sectional. Populasi penelitian seluruh kepala rumah tangga yang ada di wilayah puskesmas, sampel berjumlah 174 orang, pengambilan sampel secara purposive sampling. pengambilan data menggunakan kuesioner yang dibagikan ke responden. Penelitian telah dilakukan bulan Maret - April 2019. Analisis data secara univariat dan bivariat (Chi Square).

Hasil Penelitian : sebagian besar berperilaku tidak PHBS Rumah Tangga yaitu sebanyak 113 (64,9\%) responden. berpengetahuan PHBS Rumah Tangga kurang baik yaitu sebanyak $95(54,6 \%)$ responden. sikap PHBS Rumah Tangga negatif yaitu sebanyak $93(53,4 \%)$ responden. Ada hubungan pengetahuan ( $p$-value 0,000; OR: 4,046) dan sikap ( $p$-value 0,000; OR: 5,316) dengan perilaku PHBS Rumah Tangga.

Kesimpulan : Ada hubungan pengetahuan dan sikap dengan perilaku PHBS Rumah Tangga di Pekon Tanjung Rejo Kecamatan Bangkunat Kabupaten Pesisir Barat tahun 2019. Saran diharapkan lebih intensif dan terlibat aktif dalam kerjasama mengadakan penyuluhan berkala tentang pentingnya dan manfaat dari PHBS.

Kata kunci : pengetahuan, sikap, PHBS

\section{PENDAHULUAN}

Dalam Rencana Pembangunan Jangka Menengah Nasional (RPJMN) tahun 2015-2019, kebijakan dalam pembangunan sesuai dengan tujuan pembangunan berkelanjutan dunia atau Suistanable Development Goals (SDGs) diantaranya tujuan 6 sehat (higiene) (PHBS) untuk mewujudkan kebijakan meningkatkan pengendalian penyakit dan penyehatan lingkungan (Kemenkes, 2017). yaitu perilaku hidup bersih dan

Indikator PHBS di rumah
tangga terdiri dari persalinan
ditolong oleh tenaga kesehatan,
memberi bayi ASI eksklusif,
menimbang balita setiap bulan,
menggunakan air bersih, mencuci
tangan dengan sabun, menggunakan
jamban sehat, memberantas jentik
nyamuk, mengonsumsi buah dan
sayur setiap hari, melakukan
aktivitas fisik setiap hari dan tidak
merokok di dalam rumah
(Maryunani, 2018).
Gambaran
kesehatan di Indonesia ditunjukan

Umi Romayati Keswara ${ }^{1}$, Wahid Tri Wahyudi ${ }^{2}$, Andriyanto ${ }^{3}$

${ }^{1,2}$ Dosen Keperawatan Universitas Malahayati Lampung

${ }^{3}$ Perawat Puskesmas Bengkunat Kabupaten Lampung Barat . Email: andriyanto14@gmail.com 
dengan proporsi nasional rumah tangga (RT) dengan target PHBS sebesar $80 \%$ namun pencapaian sebesar $32,3 \%$, pencapaian tertinggi di DKI Jakarta $(56,8 \%)$ dan terendah Papua $(16,4 \%)$, terdapat 20 provinsi yang masih memiliki RT dengan PHBS dibawah pencapaian nasional salah satunya adalah Provinsi Lampung dengan urutan 5 terendah setelah Papua, Aceh, NTT dan Sumatera Barat. Cakupan pelaksanaan dari PHBS secara nasional adalah sebagai berikut: persalinan ditolong oleh tenaga kesehatan (87,6\%), memberi ASI Eksklusif (38\%), mencuci tangan dengan air bersih dan sabun (47,2\%), menggunakan jamban sehat $(81,9 \%)$, memberantas jentik di rumah $(77,4 \%)$, makan buah dan sayur setiap hari $(10,7 \%)$, melakukan aktifitas fisik setiap hari $(52,8 \%)$ serta tidak merokok di dalam rumah $\mathbf{( 7 8 , 8 \% )}$ (Riskesdas, 2013).

Cakupan PHBS di Provinsi Lampung tahun 2014 sebesar 59,2\% dengan cakupan PHBS tertinggi adalah Kabupaten Lampung Tengah sebesar 78,2\% dan terendah Kabupaten Way Kanan sebesar $33,8 \%$, sedangkan untuk kabupaten Pesisir Barat sebesar 78,2\%. Cakupan PHBS dengan pencapaian provinsi sebesr $60 \%$ di tahun 2015 tertinggi ada di Kabupaten Pesawaran sebesar 69,8\% dan terendah di Kabupaten Tulang Bawang sedangkan Kabupaten Pesisir Barat sebesar 42,7\% (Dinkes Lampung, 2016). Pencapaian PHBS provinsi Lampung di tahun 2016 sebesar $59,8 \%$ tertinggi di Kabupaten Tanggamus sebesar $75,6 \%$ dan di Kabupaten Pesisir Barat sebesar 45,8\% (Dinkes Lampung. 2017) Berdasarkan data terlihat bahwa Kabupaten Pesisir Barat mengalami pencapaian yang fluktuatif dalam cakupan PHBS dan pencapaian PHBS masih kurang dari pencapaian provinsi sebesar $59,8 \%$

$$
\text { Kabupaten Pesisir Barat }
$$
memiliki beberapa wilayah Kecamatan dengan Puskesmas yang tersebar di seluruh wilayah Kabupaten, pencapaian PHBS dengan indikator Kabupaten sebesar 45,8\%, pencapaian PHBS terendah ada di Kecamatan Bangkunat yaitu sebesar 32,19\% (Dinkes Kab. Pesisir Barat, 2017)

di Rekon Tanjung Rejo terletak pencapaian PHBS dari tahun 20132016 mengalami fluktuatif, dimana tahun 2013 dengan pencapaian PHBS sebesar 66,9\%, di tahun 2014 dengan pencapaian PHBS sebesar 73,8\%, ditahun 2015 sebesar 38,07\% dan ditahun 2016 mengalami penurunan kembali menjadi sebesar 32,19\% (Data Puskesmas, 2017). Berdasarkan data terlihat bahwa Pekon Tanjung Rejo belum melaksanakan PHBS dengan baik. PHBS masih diperlukan dan dipraktekkan dalam kehidupan sehari-hari, karena dampak dari perilaku terhadap derajat kesehatan cukup besar, maka diperlukan berbagai upaya untuk mengubah perilaku yang tidak sehat menjadi sehat, seperti memberdayakan masyarakat sehingga mampu mempraktekkan PHBS. Pengetahuan dan sikap merupakan faktor yang sangat penting untuk terbentuknya tindakan seseorang. Pengetahuan dan sikap ibu yang didasarkan dengan pemahaman yang tepat dapat menumbuhkan perilaku baru yang baik tentang suatu hal, khususnya mengenai PHBS pada keluarganya (Notoatmodjo, 2014) Menurut Notoatmodjo (2014), perilaku seseorang yang berhubungan dengan kesehatan

\footnotetext{
Umi Romayati Keswara ${ }^{1}$, Wahid Tri Wahyudi ${ }^{2}$, Andriyanto ${ }^{3}$

${ }^{1,2}$ Dosen Keperawatan Universitas Malahayati Lampung

${ }^{3}$ Perawat Puskesmas Bengkunat Kabupaten Lampung Barat . Email: andriyanto14@gmail.com
} 
dipengaruhi oleh tiga faktor yaitu faktor predisposisi yaitu pengetahuan, sikap, kepercayaan, keyakinan dan motivasi, faktor pendukung yaitu peraturan kesehatan, fasilitas dan sarana kesehatan dan faktor pendorong antara lain sikap dan peran petugas kesehatan.

Penelitian Lauson (2016) dengan hasil menunjukkan bahwa faktor-faktor yang berhubungan bermakna adalah pengetahuan tentang PHBS. Penelitian Kastari (2018) dengan hasil ada hubungan yang signifikan antara pengetahua dan sikap dengan pelaksanaan PHBS di Wilayah Binaan Puskesmas Telaga Biru. Penelitian Trisnowati (2017) Pengetahuan kepala rumah tangga tentang PHBS Rumah Tangga sebagian besar dalam kategori kurang dan cukup yaitu sebanyak 54 orang $(79,4 \%)$. Mayoritas kepala rumah tangga tidak mendukung PHBS Rumah Tangga yaitu sebanyak 39 orang $(57,4 \%)$. Ada $60(88,2 \%)$ orang merokok di dalam rumah. Selanjutnya berdasarkan uji chi square terdapat hubungan pengetahuan kepala rumah tangga tentang PHBS rumah tangga dan ada hubungan sikap terhadap PHBS rumah tangga $P$ value secara masing-masing. Penelitian Aminah (2018) Hasil penelitian menunjukkan ada hubungan pengetahuan dengan pelaksanaan PHBS di wilayah kerja Puskesmas Sombaopu Kabupaten Gowa ada hubungan sikap dengan pelaksanaan PHBS di wilayah kerja Puskesmas Sombaopu Kabupaten Gowa.

Berdasarkan data di wilayah kerja Puskesmas Bengkunat Belimbing berdasarkan cakupan kegiatan penilaian kinerja puskesmas tahun 2016 pelaksanaan PHBS rumah tangga masih kurang dari target sebesar 75\% (Puskesmas Bengkunat Belimbing, 2018). Hal ini berkaitan dengan banyak faktor yang ada pada masyarakat maupun instansi kesehatan yang ada.

Berdasarkan hasil pra survey yang dilakukan pada tanggal 6-11 Januari 2019, dari 10 kepala keluarga, dari 10 kepala keluarga, tidak ada satupun yang mengetahui tentang PHBS dan berdasarkan hasil observasi terlihat bahwa dari 10 orang kepala rumah tangga keseluruhan merokok didalam rumah, sebanyak $40 \%$ tidak memiliki jamban dengan septic tank dan jarang mengkonsumsi buah dan sudah memberikan bayi makanan tambahan dikarenakan menurut keluarga tidak ada masalah pada bayi walaupun sudah diberikan makanan tambahan.

\section{METODE PENELITIAN}

\begin{tabular}{l}
\multicolumn{1}{c}{ Jenis penelitian yang } \\
digunakan dalam penelitian ini \\
adalah penelitian kuantitatif \\
Rancangan penelitian dengan \\
pendekatan cross sectional
\end{tabular}
merupakan suatu penelitian yang mengetahui hubungan pengetahuan dan sikap dengan pelaksanaan PHBS Rumah Tangga. Populasi penelitian adalah seluruh kepala rumah tangga yang ada di wilayah puskesmas, Pengambilan sampel secara purposive sampling yaitu berdasarkan kriteria yang diinginkan oleh peneliti. Variabel yang diteliti adalah pengetahuan keluarga, sikap keluarga, dan PHBS tatanan rumah tangga. pengambilan data menggunakan kuesioner yang dibagikan ke responden. Penelitian telah dilakukan bulan Maret - April 2019. Analisis data secara univariat dan bivariat (Chi Square) dengan pengolahan data menggunakan aplikasi SPSS versi 20.

\footnotetext{
Umi Romayati Keswara ${ }^{1}$, Wahid Tri Wahyudi ${ }^{2}$, Andriyanto ${ }^{3}$

${ }^{1,2}$ Dosen Keperawatan Universitas Malahayati Lampung

${ }^{3}$ Perawat Puskesmas Bengkunat Kabupaten Lampung Barat . Email: andriyanto14@gmail.com
} 
HASIL DAN PEMBAHASAN

Analisis Univariat

Distribusi frekuensi pelaksanaan PHBS Rumah Tangga, pengetahuan keluarga dan sikap keluarga

\begin{tabular}{llcc}
\hline \multicolumn{1}{c}{ Variabel } & \multicolumn{1}{c}{ Kategori } & Frekuensi & Persentase (\%) \\
\hline Prilaku PHBS & PHBS & 61 & 35,1 \\
& Tidak PHBS & 113 & 64,9 \\
\cline { 2 - 4 } & Total & 174 & 100,0 \\
\hline \multirow{2}{*}{ Pengetahuan } & Baik & 79 & 45,4 \\
& Kurang Baik & 95 & 54,6 \\
\cline { 2 - 4 } & Total & 174 & 100,0 \\
\hline Sikap & Positif & 81 & 46,6 \\
\cline { 2 - 4 } & Negatif & 93 & 53,4 \\
\cline { 2 - 4 } & Total & 174 & 100,0 \\
\hline
\end{tabular}

Berdasarkan tabel diketahui sebagian besar berperilaku tidak PHBS Rumah Tangga yaitu sebanyak 113 (64,9\%) responden. Diketahui sebagian besar berpengetahuan PHBS Rumah Tangga kurang baik yaitu sebanyak sebanyak 95 (54,6\%) responden. Diketahui sebagian besar yang memiliki sikap PHBS Rumah Tangga negatif yaitu sebanyak $93(53,4 \%)$ responden.

Analisis Bivariat

Hubungan Pengetahuan Keluarga Dengan Perilaku PHBS

\begin{tabular}{lcccccccc}
\hline \multirow{3}{*}{ Pengetahuan } & \multicolumn{4}{c}{ Perilaku PHBS } & & \multicolumn{2}{c}{$\begin{array}{c}\boldsymbol{p} \text { - } \\
\text { value }\end{array}$} & $\begin{array}{c}\text { OR 95\% } \\
\mathbf{C l}\end{array}$ \\
\cline { 2 - 5 } & $\mathbf{n}$ & $\%$ & $\mathbf{n}$ & $\%$ & & & & \\
\hline Baik & 41 & 51,9 & 38 & 48,1 & 79 & 100 & & 4,046 \\
Kurang Baik & 20 & 21,1 & 75 & 78,9 & 95 & 100 & 0,000 & $(2,087-$ \\
Total & 61 & 35,1 & 113 & 64,9 & 174 & 100 & & $7,843)$ \\
\hline
\end{tabular}

Dari tabel diketahui dari 79 responden dengan pengetahuan baik sebanyak $41(51,9 \%)$ responden berperilaku PHBS dan sebanyak 38 $(48,1 \%)$ responden tidak berperilaku PHBS. Sedangkan dari 95 responden dengan pengetahuan kurang baik sebanyak $20 \quad(21,1 \%)$ responden berperilaku PHBS dan sebanyak 75 $(78,9 \%)$ responden tidak berperilaku PHBS.

Hasil uji statistik diperoleh $p$ value $=0,000$ yang berarti $\mathrm{p}<\mathrm{a}=$ 0,05 (Ha diterima), maka dapat disimpulkan bahwa ada hubungan pengetahuan keluarga dengan pelaksanaan PHBS Rumah Tangga di Pekon Tanjung Rejo Kecamatan Bangkunat Kabupaten Pesisir Barat tahun 2019, dengan nilai OR 4,046 berarti responden dengan pengetahuan baik memiliki peluang 4 kali lebih besar untuk berperilaku PHBS jika dibandingkan dengan responden yang pengetahuan kurang baik.

\footnotetext{
Umi Romayati Keswara ${ }^{1}$, Wahid Tri Wahyudi ${ }^{2}$, Andriyanto ${ }^{3}$

${ }^{1,2}$ Dosen Keperawatan Universitas Malahayati Lampung

${ }^{3}$ Perawat Puskesmas Bengkunat Kabupaten Lampung Barat . Email: andriyanto14@gmail.com
} 
Hubungan Sikap Dengan Perilaku PHBS

\begin{tabular}{|c|c|c|c|c|c|c|c|c|}
\hline \multirow{3}{*}{ Sikap } & \multicolumn{4}{|c|}{ Perilaku PHBS } & \multirow{3}{*}{$\mathrm{N}$} & \multirow{3}{*}{$\%$} & \multirow{3}{*}{$\begin{array}{c}p- \\
\text { value }\end{array}$} & \multirow{3}{*}{$\begin{array}{c}\text { OR 95\% } \\
\mathrm{Cl}\end{array}$} \\
\hline & \multicolumn{2}{|c|}{ PHBS } & \multicolumn{2}{|c|}{ Tidak PHBS } & & & & \\
\hline & $\mathrm{n}$ & $\%$ & $\mathrm{n}$ & $\%$ & & & & \\
\hline Positif & 44 & 54,3 & 37 & 45,7 & 81 & 100 & & 5,316 \\
\hline $\begin{array}{l}\text { Negatif } \\
\text { Total }\end{array}$ & $\begin{array}{l}17 \\
61\end{array}$ & $\begin{array}{l}18,3 \\
35,1\end{array}$ & $\begin{array}{c}76 \\
113\end{array}$ & $\begin{array}{l}81,7 \\
64,9\end{array}$ & $\begin{array}{c}93 \\
174\end{array}$ & $\begin{array}{l}100 \\
100\end{array}$ & 0,000 & $\begin{array}{l}(2,683- \\
10.534)\end{array}$ \\
\hline
\end{tabular}

Dari tabel diketahui dari 81 responden yang memiliki sikap positif sebanyak $44 \quad(54,3 \%)$ responden berperilaku PHBS dan sebanyak $37(45,7 \%)$ responden tidak berperilaku PHBS. Sedangkan dari 93 responden memiliki sikap negatif sebanyak $17 \quad(18,3 \%)$ responden berperilaku PHBS dan sebanyak $76 \quad(81,7 \%)$ responden tidak berperilaku PHBS.

Hasil uji statistik diperoleh $p$ value $=0,000$ yang berarti $\mathrm{p}<\mathrm{a}=$

\section{PEMBAHASAN}

Analisis Univariat

Distribusi frekuensi perilaku PHBS

Berdasarkan hasil penelitian sebagian besar berperilaku tidak PHBS Rumah Tangga yaitu sebanyak $113(64,9 \%)$ responden.

Menurut pendapat peneliti PHBS yang baik dapat memberikan dampak yang bermakna terhadap kesehatan dan meningkatkan kualitas sumber daya manusia dalam peningkatan derajat kesehatan, status pola gizi dan pemanfaatan sarana kesehatan lingkungan agar tercapai derajat kesehatan yang optimal. Masalah kesehatan lingkungan merupakan salah satu dari akibat masih rendahnya tingkat pendidikan penduduk, masih terikat eratnya masyarakat dengan adat istiadat kebiasaan, kepercayaan dan lain sebagainya yang tidak sejalan dengan konsep kesehatan. Keluarga
0,05 (Ha diterima), maka dapat disimpulkan bahwa ada hubungan sikap dengan perilaku PHBS Rumah Tangga di Pekon Tanjung Rejo Kecamatan Bangkunat Kabupaten Pesisir Barat tahun 2019, dengan nilai OR 5,316 berarti responden dengan sikap positif memiliki peluang 5,3 kali lebih besar untuk berperilaku PHBS jika dibandingkan dengan responden sikap negatif.

mempunyai peran penting dalam meningkatkan kualitas kesehatan masyarakat, karena dalam keluarga terjadi komunikasi dan interaksi antara anggota keluarga yang menjadi awal penting dari suatu proses pendidikan perilaku. Pelaksanaan perilaku hidup bersih dan sehat sejak dini dalam keluarga dapat menciptakan keluarga yang sehat dan aktif dalam setiap upaya kesehatan dimasyarakat.

\section{Distribusi frekuensi pengetahuan PHBS}

Berdasarkan hasil penelitian sebagian besar berpengetahuan PHBS Rumah Tangga kurang baik yaitu sebanyak sebanyak 95 (54,6\%) responden.

Menurut pendapat peneliti pengetahuan dipengaruhi oleh beberapa faktor, salah satunya adalah tingkat pendidikan yang mana secara umum, orang yang

\footnotetext{
Umi Romayati Keswara ${ }^{1}$, Wahid Tri Wahyudi ${ }^{2}$, Andriyanto ${ }^{3}$

${ }^{1,2}$ Dosen Keperawatan Universitas Malahayati Lampung

${ }^{3}$ Perawat Puskesmas Bengkunat Kabupaten Lampung Barat . Email: andriyanto14@gmail.com
} 
berpendidikan lebih tinggi akan memiliki pengetahuan yang lebih luas daripada orang yang berpendidikan lebih rendah dan dengan pendidikan dapat menambah wawasan atau pengetahuan seseorang. Pengetahuan baik dapat mengerti tentang pentingnya pola perilaku hidup bersih dan sehat (PHBS) sehingga berimplikasi pada penerapan/pelaksanaan PHBS yang baik pula.

Sebagian besar responden mengetahui dan menyadari bahwa perilaku hidup bersih dan sehat khususnya dalam penyediaan air bersih dan konsumsi air minum yang sehat, perilaku mencuci tangan yang benar serta penggunaan jamban sesuai syarat kesehatan akan menghindarkan anggota keluarga dari resiko terjadinya penyakit terutama yang ditimbulkan dari perilaku yang terkait dengan kebiasaan-kebiasaan tersebut. Meskipun demikian, masih terdapat 45,4\% responden memiliki pengetahuan yang kurang dan penerapan PHBS dalam tatanan rumah tangga yang kurang pula. Kurangnya pengetahuan responden ini dapat disebabkan beberapa faktor antara lain masih rendahnya tingkat pendidikan yang didominasi pendidikan dasar. Pengetahuan dapat membentuk keyakinan tertentu sehingga seseorang berperilaku sesuai dengan keyakinan tersebut dengan pengetahuan kesehatan lingkungan yang baik diharapkan dapat meningkatkan kesadaran masyarakat akan pentingnya menciptakan kondisi lingkungan yang sehat, sehingga dapat memutuskan rantai penularan penyakit melalui lingkungan serta perilaku hidup bersih dan sehat agar tidak mudah tertular penyakit

\section{Distibusi frekuensi sikap PHBS}

Bersadarkan hasil penelitian sebagian besar yang memiliki sikap PHBS Rumah Tangga negatif yaitu sebanyak $93(53,4 \%)$ responden.

Menurut pendapat peneliti responden yang memiliki sikap tidak baik karena kurang mendapatkan penjelasan tentang penerapan perilaku hidup bersihdan sehat (PHBS). Padahal PHBS merupakan sangat bermanfaat dalam keluarga, karena dengan perilaku hidup bersih dan sehat (PHBS) bermanfaat untuk terhindar dari penyakit, untuk itu, diharapkan keluarga dapat lebih meningkatkan perilaku hidup bersih dan sehat (PHBS).

\section{Analisis Bivariat Hubungan Pengetahuan Keluarga Dengan Perilaku PHBS}

Berdasarkan hasil penelitian diketahui dari 79 responden dengan pengetahuan baik sebanyak 41 $(51,9 \%)$ responden berperilaku PHBS menurut pendapat peneliti pengetahuan yang baik akan menghasilkan perilaku yang baik hal ini terlihat dari responden yang pengetahuannya baik maka perilaku PHBS nya pun baik namun terdapat sebanyak $38 \quad(48,1 \%)$ responden tidak berperilaku PHBS menurut pendapat peneliti karena adanya faktor lain yang mempengaruhi perilaku seperti sikap yang masih negative terkait pelaksanaan PHBS itu sendiri misalnya tau bahwa merokok itu berbahaya namun masih merokok didalam rumah atau adanya faktor lain yang mempengaruhi masyarakat sehingga belum mempraktekkan PHBS secara maksimal yaitu tidak lepas dari program Puskesmas yang menggerakan para kader kesehatan yang bekerja di wilayah kerja Puskesmas dimana selama ini kader

\footnotetext{
Umi Romayati Keswara ${ }^{1}$, Wahid Tri Wahyudi ${ }^{2}$, Andriyanto ${ }^{3}$

${ }^{1,2}$ Dosen Keperawatan Universitas Malahayati Lampung

${ }^{3}$ Perawat Puskesmas Bengkunat Kabupaten Lampung Barat . Email: andriyanto14@gmail.com
} 
kesehatan belum menjalankan perannya secara maksimal artinya belum terjun secara aktif hanya menganjurkan kepada keluarga belum ada tindakan setiap ada kegiatan posyandu yang dilakukan di wilayah kerja Puskesmas, terlihat kegiatan belum berjalan dengan baik adapun juga aturan-aturan yang di buat dari kelurahan di wilayah kerja Puskesmas untuk larangan membuang sampah sembarangan belum maksimal sehingga masyarakat juga belum terdorong untuk patuh terhadap aturan yang di buat dan ditambah juga kurangnya perlombaan yang dibuat oleh pemerintah kota yaitu lomba kebersihan desa sehingga masyarakat tidak terdorong untuk membuat lingkungan bersih dan berdampak terhadap kesehatan mereka dan juga faktor kebiasan dalam keluarga yang berperilaku hidup sehat yang mempengaruhi individu di dalam keluarga

Berdasarkan hasil penelitian diketahui dari 95 responden dengan pengetahuan kurang baik sebanyak $20(21,1 \%)$ responden berperilaku PHBS menurut pendapat peneliti hal ini dapat terjadi karena adanya faktor kebiasaan yang dilakukan oleh keluarga terkait kebiasaan kebiasaan yang dilakukan tersebut merupakan kebiasaan yang positif sehingga walaupun pengetahuan kurang tentang PHBS rumah tangga namun dikarenakan tindakan tersebut sudah terbiasa dilakukan oleh keluarga seperti tidak merokok dalam ruangan, mengkonsumsi sayur dan buah setiap hari, menimbang balita ke posyandu sehingga responden masuk dalam ketegori perilaku PHBS dengan baik dan sebanyak $75(78,9 \%)$ responden tidak berperilaku PHBS menurut peneliti kebiasaan tidak berperilaku PHBS ini terjadi dikarenakan kurangnya pemahaman masyarakat tentang syarat kesehatan dan perilaku hidup bersih dan sehat. Semakin tinggi tingkat pendidikan responden maka semakin rendah kemungkinan mempunyai kebiasaan PHBS. Pendidikan individu berkaitan dengan tingkat penegetahuan yang dimiliki. Hasil penelitian menunjukkan bahwa mayoritas responden mempunyai tingkat pengetahuan dalam kategori rendah. tingkat pengetahuan yang kurang dapat mempengaruhi kurangnya penerapan PHBS dikeluarga. Hasil dari penelitian ini menunjukan bahwa terdapat hubungan yang bermakna antara tingkat pengetahuan dengan penerapan perilaku hidup bersih dan sehat (PHBS). Hal ini membuktikan bahwa pengetahuan sangat berperan penting dalam penerapan perilaku hidup bersih dan sehat (PHBS).

\section{Hubungan Sikap Dengan Perilaku PHBS}

Berdasarkan hasil penelitian diketahui bahwa dari 81 responden yang memiliki sikap positif sebanyak $44 \quad(54,3 \%)$ responden berperilaku PHBS menurut peneliti terbentuknya sikap yang positif kaitannya dengan penerapan perilaku hidup bersih dan sehat (PHBS) juga dipengaruhi oleh pengetahuan yang dimiliki oleh individu tersebut. Pengetahuan merupakan dasar yang penting untuk terbentuknya tindakan seseorang, pengetahuan itu sendiri penting untuk mendukung psikis dan perilaku setiap hari sehingga pengetahuan merupakan faktor yang mendukung tindakan seseorang dan sebanyak $37(45,7 \%)$ responden tidak berperilaku PHBS menurut peneliti hal ini dapat disebabkan kurangnya pengetahuan tentang arti

\footnotetext{
Umi Romayati Keswara ${ }^{1}$, Wahid Tri Wahyudi ${ }^{2}$, Andriyanto ${ }^{3}$

${ }^{1,2}$ Dosen Keperawatan Universitas Malahayati Lampung

${ }^{3}$ Perawat Puskesmas Bengkunat Kabupaten Lampung Barat . Email: andriyanto14@gmail.com
} 
pentingnya PHBS selain itu kurangnya sosialisasi atau informasi tentang PHBS rumah tangga baik yang dilakukan oleh dinas kesehatan maupun dari pemerintah desa karena semakin banyaknya sumber informasi maka semakin baik informasi yang didapat oleh seseorang didukung juga media yang digunakan yang juga dapat mempengaruhi seseorang dalam bersikap.

Berdasarkan hasil penelitian diketahui dari 93 responden memiliki sikap negatif sebanyak 17 $(18,3 \%)$ responden berperilaku PHBS menurut pendapat peneliti hal ini dimungkinkan adanya dorongan dari pihak lain atau adanya faktor lain sehingga walaupun responden memiliki sikap yang negative namun tetap melaksanakan PHBS rumah tangga dengan baik dan sebanyak $76 \quad(81,7 \%)$ responden tidak berperilaku PHB menurut pendapat peneliti sikap negatif klien tersebut disebabkan karena responden belum memahami sepenuhnya tentang beberapa perilaku hidup bersih dan sehat dalam kehidupan sehari-hari khususnya dalam tatanan rumah tangga. Sehingga pelaksanaan PHBS lewat perilaku pun tidak maksimal. Padahal aspek pengetahuan secara menyeluruh sangat lah penting peranannya dalam membentuk sikap positif terlebih lagi dalam perwujudannya dalam bentuk perilaku sehari-hari.

Menurut pendapat peneliti adanya sikap positif dan sikap negatif tersebut tidak terlepas dari tingkat pendidikan dan pengetahuan yang dimiliki. Hal ini didukung dengan masih adanya persepsi masyarakat seperti bersalin dengan paraji atau merokok dalam ruangan bukan hal buruk atau merugikan orang lain, tidak menimbulkan pencemaran dan penyakit. Selain itu sikap negative dimana masih banyak responden merokok di dalam rumah masih merupakan hal yang paling banyak terjadi. Keluarga mempunyai peran penting dalam meningkatkan kualitas kesehatan masyarakat, karena dalam keluarga terjadi komunikasi dan interaksi antara anggota keluarga yang menjadi awal penting dari suatu proses pendidikan perilaku. Pelaksanaan perilaku hidup bersih dan sehat sejak dini dalam keluarga dapat menciptakan keluarga yang sehat dan aktif dalam setiap upaya kesehatan di masyarakat

\section{KESIMPULAN}

Sebagian besar berperilaku tidak PHBS Rumah Tangga yaitu sebanyak 113 (64,9\%) responden. Sebagian besar berpengetahuan PHBS Rumah Tangga kurang baik yaitu sebanyak sebanyak 95 (54,6\%) responden. Sebagian besar yang memiliki sikap PHBS Rumah Tangga negatif yaitu sebanyak $93(53,4 \%)$ responden. Ada hubungan pengetahuan dengan perilaku PHBS Rumah Tangga di Pekon Tanjung Rejo Kecamatan Bangkunat Kabupaten Pesisir Barat tahun 2019 (p-value 0,000; OR: 4,046). Ada hubungan sikap dengan perilaku PHBS Rumah Tangga di Pekon Tanjung Rejo Kecamatan Bangkunat Kabupaten Pesisir Barat tahun 2019 ( $p$-value 0,000; OR: 5,316).

\section{SARAN}

Bagi Pekon Tanjung Rejo Kecamatan Bangkunat diharapkan lebih intensif dan terlibat aktif dalam kerjasama mengadakan penyuluhan berkala tentang pentingnya dan manfaat dari PHBS. Diadakannnya lomba antar desa, LLebih mengaktifkan kader yang bergerak dalam PHBS rumah tangga seperti kader

\footnotetext{
Umi Romayati Keswara ${ }^{1}$, Wahid Tri Wahyudi ${ }^{2}$, Andriyanto ${ }^{3}$

${ }^{1,2}$ Dosen Keperawatan Universitas Malahayati Lampung

${ }^{3}$ Perawat Puskesmas Bengkunat Kabupaten Lampung Barat . Email: andriyanto14@gmail.com
} 
mengadakan kerja bakti yang dilakukan secara rutin setiap minggu dengan jadwal yang telah di sepakati oleh warga.

Bagi Peneliti Lanjutan diharapkan kepada peneliti selanjutnya agar

\section{DAFTAR PUSTAKA}

Aminah, S. (2018). Pengetahuan Dan Sikap Keluarga Dalam Pelaksanaan Perilaku Hidup Bersih Dan Sehat Di Wilayah Kerja Puskesmas Sombaopu Gowa. Media Keperawatan: Politeknik Kesehatan Makassar, 9(1), 39-52.

Isnainy, U. C. A. S., Zainaro, M. A., Novikasari, L., Ariyanti, L., \& Furqoni, P. D. (2020). Pendidikan Kesehatan Tentang Perilaku Hidup Bersih Dan Sehat (PHBS) Di SMA Negeri 13 Bandar Lampung. Jurnal Kreativitas Pengabdian Kepada Masyarakat (Pkm), 3(1), 27-33.

Kastari, S. (2018). Faktor-Faktor Yang Berhubungan Dengan Pelaksanaan Perilaku Hidup Bersih Dan Sehat Di Rumah Tangga Di Wilayah Kerja Upk Puskesmas Telaga Biru Kelurahan Siantan Hulu Pontianak Utara. Sanitarian Jurnal Kesehatan, 9 (1), 114123.

KeMenKes, R. I. (2017). Profil kesehatan Indonesia tahun 2016. Jakarta: Kementerian Kesehatan Republik Indonesia.

Lauson, H. J. (2016). Faktor-Faktor yang Berhubungan dengan Perilaku Hidup Bersih dan Sehat Rumah Tangga Di Kecamatan Turi Sleman Yogyakarta (Doctoral dapat melanjutkan penelitian ini dengan mengamati variabelvariabel yang ada di dalam Perilaku Hidup Bersih dan Sehat.

dissertation, Universitas Gadjah Mada).

Lampung, D. K. P. (2016). Profil Provinsi Lampung Tahun 2015. Bandar Lampung: Dinas Kesehatan Pemerintah Povinsi Lampung.

Lampung, D. K. P. (2017). Profil Provinsi Lampung Tahun 2016. Bandar Lampung: Dinas Kesehatan Pemerintah Povinsi Lampung.

Maryunani, A. (2018). Perilaku hidup bersih dan sehat (PHBS). Jakarta: Trans info media.

Notoatmodjo, S. (2014). Kesehatan masyarakat ilmu dan seni. Rineka Cipta, Jakarta.

Notoatmodjo, S. (2014). Ilmu Prilaku Kesehatan. Jakarta : Rineka Cipta.

Puskesmas Bengkunat Belimbing (2018). Profil Puskesmas Bengkunat Belimbing 2017. Kabupaten Pesisir Barat.

Trisnowati, H., \& Daduk, S. S. (2017). Hubungan Pengetahuan Dan Sikap Terhadap PHBS Di Rumah Tangga Dengan Perilaku Merokok Dalam Rumah Kepala Rumah Tangga Di Dusun Karangnongko Yogyakarta. Medika Respati, 12(4).

\footnotetext{
Umi Romayati Keswara ${ }^{1}$, Wahid Tri Wahyudi ${ }^{2}$, Andriyanto ${ }^{3}$

${ }^{1,2}$ Dosen Keperawatan Universitas Malahayati Lampung

${ }^{3}$ Perawat Puskesmas Bengkunat Kabupaten Lampung Barat . Email: andriyanto14@gmail.com
} 